\title{
L-Theanine Administration Modulates the Absorption of Dietary Nutrients and Expression of Transporters and Receptors in the Intestinal Mucosa of Rats
}

\author{
Qiongxian Yan, ${ }^{1,2}$ Haiou Tong, ${ }^{2}$ Shaoxun Tang, ${ }^{1,3}$ Zhiliang Tan, ${ }^{1,3}$ \\ Xuefeng Han, ${ }^{1,2}$ and Chuanshe Zhou ${ }^{1,3}$ \\ ${ }^{1}$ Key Laboratory of Agro-Ecological Processes in Subtropical Region, Hunan Research Center of Livestock \& Poultry Sciences, \\ South-Central Experimental Station of Animal Nutrition and Feed Science in Ministry of Agriculture, Institute of Subtropical \\ Agriculture, The Chinese Academy of Sciences, Changsha, Hunan 410125, China \\ ${ }^{2}$ Hunan Co-Innovation Center for Utilization of Botanical Functional Ingredients, Changsha 410128, China \\ ${ }^{3}$ Hunan Co-Innovation Center of Animal Production Safety, CICAPS, Changsha, Hunan 410128, China \\ Correspondence should be addressed to Zhiliang Tan; zltan@isa.ac.cn
}

Received 20 March 2017; Revised 3 June 2017; Accepted 15 June 2017; Published 24 July 2017

Academic Editor: Anton M. Jetten

Copyright (c) 2017 Qiongxian Yan et al. This is an open access article distributed under the Creative Commons Attribution License, which permits unrestricted use, distribution, and reproduction in any medium, provided the original work is properly cited.

\begin{abstract}
L-theanine has various advantageous functions for human health; whether or not it could mediate the nutrients absorption is unknown yet. The effects of L-theanine on intestinal nutrients absorption were investigated using rats ingesting L-theanine solution $(0,50,200$, and $400 \mathrm{mg} / \mathrm{kg}$ body weight $)$ per day for two weeks. The decline of insulin secretion and glucose concentration in the serum was observed by L-theanine. Urea and high-density lipoprotein were also reduced by $50 \mathrm{mg} / \mathrm{kg} \mathrm{L}$-theanine. Jejunal and ileac basic amino acids transporters SLC7a1 and SLC7a9, neutral SLC1a5 and SLC16a10, and acidic SLC1a1 expression were upregulated. The expression of intestinal SGLT3 and GLUT5 responsible for carbohydrates uptake and GPR120 and FABP2 associated with fatty acids transport were inhibited. These results indicated that L-theanine could inhibit the glucose uptake by downregulating the related gene expression in the small intestine of rats. Intestinal gene expression of transporters responding to amino acids absorption was stimulated by L-theanine administration.
\end{abstract}

\section{Introduction}

L-theanine, as a non-protein-forming amino acid (AA), contributes to the umami taste and unique flavor of green tea. Its content in tea leaves is closely related to the quality and price of green tea $[1,2]$. L-theanine is beneficial for remedying various nutritional and metabolic diseases in human, including providing antiobesity effects [3, 4], suppressing the body weight increases and fat accumulation $[3,5]$, and exerting antidiabetic effects $[6,7]$. L-theanine is transported through the intestinal brush border membrane mainly via neutral AA systems B, A, ASC, N, and L, based on findings that L-theanine inhibited the absorption of glutamine and large neutral amino acids (AAs, leucine, and tryptophan) into organs [8-10]. Our knowledge data and previous findings also confirmed that most neutral AAs (threonine, valine, methionine, isoleucine, serine, alanine, tyrosine, and leucine) and certain basic AA (lysine) in the serum of L-theanineadministered rats were decreased $[8,11]$. These researches indicated that L-theanine could competitively suppress the absorption of AAs.

However, AAs absorption is dependent on the activities of AA transporters located in the brush border membrane of small intestine. Neutral AA transporters, solute carrier family 1, member 5 (SLC1a5) and family 16, member 10 (SLC16a10), are responsible for threonine, serine, alanine, cysteine, glutamine and phenylalanine, tyrosine, and tryptophan transporting, respectively. Basic AA transporters, solute carrier family 7, member 1 (SLC7a1) and member 9 (SLC7a9), are in charge of transporting arginine, lysine, histidine, alanine, serine, cysteine, threonine, asparagine, and glutamine. Acidic AA transporters solute carrier family 1, member 1 (SLCla1) 
and member 2 (SLC1a2) transport glutamate and aspartate. It is reported that L-theanine competitively inhibited the uptake of glutamate substrate through solute carrier family 1 , member 3 (SLC1a3) and SLC1a2 expressed in cancer cells $[12,13]$. However, the expression pattern of glutamate transporter subtypes in tumor cells is different from normal cells. Therefore, it is necessary to investigate the efficacy of L-theanine on glutamate transporters in normal tissues. Whether or not the expression of different AA transport systems is mediated by L-theanine is unknown yet.

Furthermore, it is reported that the fatty accumulation in mice was suppressed by the administration of green tea powder [4] and theanine was responsible for this suppressive effect [3]. Although serum glucose in rats was not changed, the insulin was reduced by oral theanine [14]. These literatures indicate that metabolism of lipid and insulin is regulated by L-theanine. In the enterocytes of rats, there are many transporters and receptors responses to sugar and fatty acids transport, including sodium dependent glucose transporters (SGLTs), glucose transporters, G-protein-coupled receptors, and fatty acid binding protein 2 (FABP2) [15-21]. Whether these transporters and receptors involved in the regulation of L-theanine administration on absorption of glucose and lipid is unclear. Based on these questions, we measured the nutrient content in the blood and mRNA expression of related transporters and receptors in small intestine of rats after the intragastric administration of L-theanine for two weeks, aiming at figuring out the preliminary L-theanine-induced regulation mechanism in nutrients absorption in rats.

\section{Material and Methods}

2.1. Experimental Design. This experiment was conducted according to the animal care guidelines of the Animal Care Committee, Institute of Subtropical Agriculture, the Chinese Academy of Sciences, Changsha city, Hunan province, China (number KYNEAAM-2013-0009). Sixty-four Sprague Dawley (SD) rats which are 3 weeks old weighing 74-92.2 g were used as experimental animals. The management of SD rats and L-theanine administration experiment was the same as $\mathrm{Li}$ et al. [22]. The animals were individually housed in plastic cages under laboratory conditions $\left(25 \pm 3^{\circ} \mathrm{C}, 70 \pm\right.$ $5 \%$ relative humidity, good ventilation, and a 12 -h light-dark cycle) and had free access to food and pure water. After three days of adaptation, SD rats were randomly divided into four treatment groups. Each group contained eight male rats and eight female rats. During fasting (15:00-17:00 h), rats in the treatments received gastric intubation of four different doses of L-theanine $(0,50,200$, and $400 \mathrm{mg} / \mathrm{kg}$ body weight/day), respectively. L-theanine was freshly dissolved in $0.9 \% \mathrm{NaCl}$ solution in advance before intubation every day. $1 \mathrm{~mL}$ of the L-theanine solution was daily administered to each rat for two weeks.

2.2. Blood and Tissue Samples Collection. At the end of the experiment, SD rats were fasted overnight and anesthetized by ether for $4 \mathrm{~min}$, and then blood was collected from the jugular vein into tubes without anticoagulant. The blood samples were centrifuged at $3500 \mathrm{rpm}$ for $15 \mathrm{~min}$ at $4^{\circ} \mathrm{C}$, and then serum samples were collected and stored at $-80^{\circ} \mathrm{C}$ until assay. The whole jejunum and ileum segments were collected and rinsed with ice-cold saline $(0.9 \% \mathrm{NaCl}$ wt/vol $)$. Then the mucosae were carefully removed, quickly frozen in liquid nitrogen, and stored at $-80^{\circ} \mathrm{C}$ prior to subsequent analyses.

2.3. Analysis of Serum. The glucose, total cholesterol, triglyceride (TG), urea, low-density lipoprotein cholesterol (LDL), and high-density lipoprotein cholesterol (HDL) were determined by automatic biochemistry analyzer (Synchron Clinical System CX4 PRO, Beckman Coulter, USA) according to the instructions. Insulin was assayed by the ELISA kit purchased from Huamei Biotechnology Co., Ltd. (Wuhan, Hubei, China). Non-esterified fatty acids (NEFA) were measured by kit produced by Nanjing Jiancheng Bioengineering Institute (Nanjing, Jiangsu, China).

2.4. Real-Time Quantitative PCR. Total RNA was isolated from the mucosa of jejunum and ileum using the Trizol Reagent (Invitrogen, USA), and $c$ DNA was synthesized using the Revert Aid First Strand $c$ DNA synthesis kit (Applied Biosystems, Thermo Fisher Scientific, USA). For relative quantification of gene expression, the ABI Prism 7900 HT Fast Real-Time PCR System (Applied Biosystems, Foster, CA) was used. Primers were designed using the Primer 3 plus program, and sequences are listed in Table 1 . The reaction system contained $5 \mu \mathrm{L} \mathrm{SYBR}{ }^{\circledR}$ Premix Ex Taq ${ }^{\mathrm{TM}}(2 \mathrm{x}), 0.4 \mu \mathrm{L}$ PCR forward primer $(10 \mu \mathrm{M}), 0.4 \mu \mathrm{L}$ PCR reverse primer $(10 \mu \mathrm{M}), 0.2 \mu \mathrm{L}$ ROX reference dye (50x), $1.0 \mu \mathrm{L} c \mathrm{DNA}$, and $3 \mu \mathrm{L}$ sterilized $\mathrm{ddH}_{2} \mathrm{O}$. The thermal profile for all reactions was $30 \mathrm{~s}$ at $95^{\circ} \mathrm{C}$, then 40 cycles of denaturation at $95^{\circ} \mathrm{C}$ for $5 \mathrm{~s}$, and annealing at $60^{\circ} \mathrm{C}$ for $30 \mathrm{~s}$. Each reaction was completed with a melting curve analysis to ensure the specificity of the reaction. All the samples were analyzed in duplicate, and the relative amount of each specific transcript was obtained after normalization against the endogenous control $\beta$-actin. The relative amounts of target genes were quantified according to the $2^{-\Delta \Delta \mathrm{CT}}$ method [23].

2.5. Statistical Analysis. Statistical analyses were conducted by one-way analysis of variance (ANOVA) using the Mixed Proc of SAS (version 8.2, SAS Institute, Cary, NC, USA). The main effect tested was the dose of L-theanine. When indicated by ANOVA, means were separated using least significant differences. Significance was declared at $P<0.05$.

\section{Results}

As shown in Table 2, glucose concentration was decreased by $400 \mathrm{mg} / \mathrm{kg}$ L-theanine administration compared to the control group $(0 \mathrm{mg} / \mathrm{kg}$ L-theanine administration $)(P<0.05)$. Insulin concentration was linearly decreased by L-theanine administration $(P<0.001)$. There were no differences $(P>$ $0.05)$ in the serum cholesterol, TG, NEFA, and LDL concentrations among the L-theanine treatments. Concentrations of urea and HDL were decreased by $50 \mathrm{mg} / \mathrm{kg}$ L-theanine treatment compared to the control group $(P<0.05)$.

Transcript levels of intestinal AA transporters in the intestine of rats are shown in Table 3. Expression of acidic 
TABLE 1: Sequences of primers used for real-time quantitative PCR.

\begin{tabular}{|c|c|c|c|}
\hline Gene & GenBank accession & Primer & Length (bp) \\
\hline SLC7a1 & NM_013111.3 & $\begin{array}{l}\text { Forward-CCTTCATCACTGGCTGGAAC } \\
\text { Reverse-GGTTTGCCTATCAGCTCGTC }\end{array}$ & 100 \\
\hline SLCla5 & NM_175758.3 & $\begin{array}{c}\text { Forward-GGAGAAATGGACTGGGTGTG } \\
\text { Reverse-CCAGCAAGAAGGCTCTGAAT }\end{array}$ & 107 \\
\hline SLCla2 & NM_001035233.1 & $\begin{array}{c}\text { Forward-GGCAGTCATCTCCCTGTTGA } \\
\text { Reverse-AGACATTCATCCCGTCCTTG }\end{array}$ & 101 \\
\hline SLCla1 & NM_013032.3 & $\begin{array}{l}\text { Forward-GGAGTCTTGGTTCGAGGACA } \\
\text { Reverse-GTGGCAGAATGACGAGCTTC }\end{array}$ & 106 \\
\hline SLC16a10 & NM_138831.1 & $\begin{array}{l}\text { Forward-TCACTGGTCATTCTGGGACA } \\
\text { Reverse-CCTAACAGCAAAGGGAGCAA }\end{array}$ & 107 \\
\hline SLC7a9 & NM_053929.1 & $\begin{array}{l}\text { Forward-ACCAAGTCAGGGGGTGAGTA } \\
\text { Reverse-AGATGATGGCGAAGGATGAG }\end{array}$ & 115 \\
\hline SGLT1 & NM_013033 & $\begin{array}{l}\text { Forward-GCCATCATCCTCTTCGCTAT } \\
\text { Reverse-CGCTCTTCTGTGCTGTTACG }\end{array}$ & 122 \\
\hline SGLT3 & NM_001106383 & $\begin{array}{l}\text { Forward-GATGCTGGTGCTGAAACTGA } \\
\text { Reverse-CGCTGTTGAAGATGGAGGTC }\end{array}$ & 101 \\
\hline GLUT2 & NM_012879 & $\begin{array}{l}\text { Forward-GATTGCTCCAACCACACTCA } \\
\text { Reverse-CCTGATTGCCCAGAATGAAG }\end{array}$ & 113 \\
\hline GLUT5 & NM_031741 & $\begin{array}{l}\text { Forward-GGGCTCTTGGTCACACACA } \\
\text { Reverse-CGTCTTGTCTCTCGGCAACT }\end{array}$ & 108 \\
\hline FATP & NM_053580.2 & $\begin{array}{l}\text { Forward-GGAAGGTTGCTGTGGTGTTC } \\
\text { Reverse-ATGGGAGCCAGAAGGGTAGA }\end{array}$ & 120 \\
\hline GPR43 & NM_001005877 & $\begin{array}{l}\text { Forward-AGGCTGTGGTGTTCAGTTCC } \\
\text { Reverse-GGGATTGCGGAGTAGTAGCA }\end{array}$ & 113 \\
\hline GPR120 & NM_001047088.1 & $\begin{array}{l}\text { Forward-AGACCACCGTTCTGGGACT } \\
\text { Reverse-GAAGAGGTTGAGCACCAAGC }\end{array}$ & 119 \\
\hline$F A B P 2$ & NM_013068.1 & $\begin{array}{l}\text { Forward-GAGGCCAAGCGGATCTTTA } \\
\text { Reverse-TGCATTATCAGCGAGATGGA }\end{array}$ & 109 \\
\hline$\beta$-actin & NM_031144.3 & $\begin{array}{l}\text { Forward-TGTCACCAACTGGGACGATA } \\
\text { Reverse-GGGGTGTTGAAGGTCTCAAA }\end{array}$ & 165 \\
\hline
\end{tabular}

TABLE 2: Effects of L-theanine administration on average daily gain and biochemical parameters in serum of rats.

\begin{tabular}{|c|c|c|c|c|c|c|}
\hline \multirow{2}{*}{ Item } & \multicolumn{4}{|c|}{ Treatments $(\mathrm{mg} / \mathrm{kg} \mathrm{BW} \cdot \mathrm{d})$} & \multicolumn{2}{|c|}{$P$ value } \\
\hline & 0 & 50 & 200 & 400 & Linear & Quadratic \\
\hline Average daily gain, g/d & $5.24 \pm 0.17^{b}$ & $6.01 \pm 0.17^{\mathrm{a}}$ & $6.15 \pm 0.17^{\mathrm{a}}$ & $5.98 \pm 0.17^{\mathrm{a}}$ & 0.038 & $<0.01$ \\
\hline Glucose, mM & $5.65 \pm 0.29^{\mathrm{a}}$ & $5.31 \pm 0.29^{\mathrm{ab}}$ & $5.74 \pm 0.29^{\mathrm{a}}$ & $4.77 \pm 0.30^{\mathrm{b}}$ & NS & NS \\
\hline Insulin, uIU/mL & $43.2 \pm 2.18^{\mathrm{a}}$ & $41.7 \pm 2.18^{\mathrm{a}}$ & $26.3 \pm 2.26^{\mathrm{b}}$ & $19.0 \pm 3.08^{\mathrm{c}}$ & $<0.001$ & NS \\
\hline Cholesterol, mM & $2.23 \pm 0.09$ & $2.08 \pm 0.09$ & $2.13 \pm 0.09$ & $2.05 \pm 0.09$ & NS & NS \\
\hline Triglyceride, mM & $1.23 \pm 0.07$ & $1.21 \pm 0.07$ & $1.02 \pm 0.07$ & $1.16 \pm 0.07$ & NS & NS \\
\hline NEFA, mM & $1.27 \pm 0.13$ & $1.35 \pm 0.10$ & $1.45 \pm 0.11$ & $1.31 \pm 0.10$ & NS & NS \\
\hline Urea, mM & $5.42 \pm 0.16^{\mathrm{a}}$ & $4.85 \pm 0.16^{\mathrm{b}}$ & $5.70 \pm 0.16^{\mathrm{a}}$ & $5.38 \pm 0.17^{\mathrm{a}}$ & NS & NS \\
\hline $\mathrm{LDL}, \mathrm{mM}$ & $0.339 \pm 0.02$ & $0.341 \pm 0.02$ & $0.354 \pm 0.02$ & $0.347 \pm 0.02$ & NS & NS \\
\hline HDL, mM & $1.74 \pm 0.06^{\mathrm{a}}$ & $1.52 \pm 0.06^{\mathrm{b}}$ & $1.60 \pm 0.06^{\mathrm{ab}}$ & $1.60 \pm 0.06^{\mathrm{ab}}$ & NS & NS \\
\hline
\end{tabular}

BW: body weight, NEFA: non-esterified fatty acids, LDL: low-density lipoprotein, HDL: high-density lipoprotein, and NS: not significant. ${ }^{\text {a-c }}$ Means within a row not bearing a common superscript letter differ $(P<0.05)$. Data were reported as mean \pm SE. Data of average daily gain were cited by Tong et al. $(2016)$.

AA transporter SLC1a1 was upregulated in the jejunum and ileum (Quadratic, $P<0.001$ ), while jejunal SLC1a2 transcript was linearly decreased $(P<0.001)$ with the increasing doses of L-theanine but increased by L-theanine treatments in the ileum (Quadratic, $P<0.05$ ). Expression of neutral AA transporter SLC1a5 was increased by doses of L-theanine (jejunum, Linear, $P<0.001$; ileum, Linear and Quadratic, $P<0.001)$; therein the maximal values both occurred in the $400 \mathrm{mg} / \mathrm{kg}$ L-theanine treatment. Another neutral AA transporter SLC16a10 expression in the jejunum and ileum was upregulated by doses of L-theanine (Quadratic, $P<$ 0.001). Basic AA transporters SLC7al (jejunum, Linear, $P<$ 
TABLE 3: Effects of L-theanine administration on the transcript levels of AA transporters in rat intestine.

\begin{tabular}{|c|c|c|c|c|c|c|}
\hline \multirow{2}{*}{ Item } & \multicolumn{4}{|c|}{ Treatments (mg/kg BW·d) } & \multicolumn{2}{|c|}{$P$ value } \\
\hline & 0 & 50 & 200 & 400 & Linear & Quadratic \\
\hline \multicolumn{7}{|l|}{ Jejunum } \\
\hline SLC1a1 & $1.00^{\mathrm{b}}$ & $1.71 \pm 0.43^{\mathrm{b}}$ & $7.70 \pm 0.50^{\mathrm{a}}$ & $1.12 \pm 0.55^{\mathrm{b}}$ & NS & $<0.001$ \\
\hline SLC1a2 & $1.00^{\mathrm{a}}$ & $0.34 \pm 0.06^{\mathrm{c}}$ & $0.63 \pm 0.07^{\mathrm{b}}$ & $0.23 \pm 0.07^{\mathrm{c}}$ & $<0.001$ & NS \\
\hline SLC1a5 & $1.00^{\mathrm{b}}$ & $1.77 \pm 0.43^{\mathrm{b}}$ & $1.61 \pm 0.38^{\mathrm{b}}$ & $3.49 \pm 0.41^{\mathrm{a}}$ & $<0.001$ & NS \\
\hline SLC16a10 & $1.00^{\mathrm{c}}$ & $7.17 \pm 0.84^{\mathrm{a}}$ & $5.25 \pm 0.79^{\mathrm{ab}}$ & $3.83 \pm 0.68^{\mathrm{b}}$ & NS & $<0.001$ \\
\hline SLC7a1 & $1.00^{\mathrm{c}}$ & $8.40 \pm 0.70^{\mathrm{a}}$ & $3.93 \pm 0.90^{\mathrm{b}}$ & $8.88 \pm 1.28^{\mathrm{a}}$ & 0.0017 & NS \\
\hline SLC7a9 & $1.00^{c}$ & $6.40 \pm 0.60^{\mathrm{b}}$ & $10.9 \pm 0.66^{\mathrm{a}}$ & $1.70 \pm 0.60^{\mathrm{c}}$ & NS & $<0.001$ \\
\hline \multicolumn{7}{|l|}{ Ileum } \\
\hline SLC1a1 & $1.00^{\mathrm{b}}$ & $4.89 \pm 0.35^{\mathrm{a}}$ & $5.11 \pm 0.39^{\mathrm{a}}$ & $1.25 \pm 0.39^{\mathrm{b}}$ & NS & $<0.001$ \\
\hline SLC1a2 & 1.00 & $1.47 \pm 0.29$ & $1.86 \pm 0.24$ & $1.02 \pm 0.44$ & NS & 0.01 \\
\hline SLC1a5 & $1.00^{\mathrm{b}}$ & $1.45 \pm 0.35^{\mathrm{b}}$ & $0.94 \pm 0.37^{\mathrm{b}}$ & $4.45 \pm 0.45^{\mathrm{a}}$ & $<0.001$ & $<0.001$ \\
\hline SLC16a10 & $1.00^{c}$ & $8.27 \pm 0.27^{b}$ & $13.1 \pm 0.63^{\mathrm{a}}$ & $1.52 \pm 0.77^{\mathrm{c}}$ & NS & $<0.001$ \\
\hline SLC7a1 & $1.00^{\mathrm{b}}$ & $1.71 \pm 0.34^{\mathrm{b}}$ & $1.18 \pm 0.36^{\mathrm{b}}$ & $4.62 \pm 0.45^{\mathrm{a}}$ & $<0.001$ & $<0.001$ \\
\hline SLC7a9 & $1.00^{\mathrm{b}}$ & $1.93 \pm 0.42^{\mathrm{b}}$ & $7.21 \pm 0.52^{\mathrm{a}}$ & $2.09 \pm 0.42^{\mathrm{b}}$ & $<0.001$ & $<0.001$ \\
\hline
\end{tabular}

BW: body weight, SLCla1: solute carrier family 1, member 1, SLC1a2: solute carrier family 1, member 2, SLC1a5: solute carrier family 1, member 5, SLC16a10: solute carrier family 16, member 10, SLC7a1: solute carrier family 7, member 1, SLC7a9: solute carrier family 7, member 9, and NS: not significant. ${ }^{\text {a-c }}$ Means within a row not bearing a common superscript letter differ $(P<0.05)$. Data were reported as mean $\pm \mathrm{SE}$.

0.01; ileum, Linear and Quadratic, $P<0.001)$ and SLC7a9 expression (jejunum, Quadratic, $P<0.001$; ileum, Linear and Quadratic, $P<0.001$ ) was increased with the increasing doses of L-theanine.

Gene expressions of glucose transporters and receptors in the intestine of rats are shown in Table 4. Transcript level of $S G L T 1$ in the jejunum was stimulated $(P<0.05)$ by $400 \mathrm{mg} / \mathrm{kg}$ L-theanine compared to the $200 \mathrm{mg} / \mathrm{kg} \mathrm{L}$-theanine treatment, while in the ileum it was downregulated (Quadratic, $P<$ 0.001 ); therein a minimum value appeared at the $200 \mathrm{mg} / \mathrm{kg}$ L-theanine group. SGLT3 expression in the jejunum and ileum was decreased by L-theanine treatment (jejunum, Linear, $P<0.001$; ileum, Linear and Quadratic, $P<0.001$ ). Comparing with the $50 \mathrm{mg} / \mathrm{kg} \mathrm{L}$-theanine treatment, jejunal GLUT2 expression was suppressed $(P<0.05)$ by $200 \mathrm{mg} / \mathrm{kg}$ L-theanine. Ileac GLUT2 expression was upregulated $(P<$ $0.01)$ by $50 \mathrm{mg} / \mathrm{kg} \mathrm{L}$-theanine and then inhibited $(P<0.05)$ by high doses of L-theanine treatments compared to $50 \mathrm{mg} / \mathrm{kg}$ L-theanine. Jejunal GLUT5 expression was inhibited $(P<$ 0.05 ) by high doses of L-theanine treatment compared to the control group, while its expression in the ileum was linearly decreased $(P<0.01)$ by increasing doses of L-theanine.

The mRNA abundance of the fatty acid transporters and receptors in the intestine of rats is shown in Table 5. Jejunal FATP expression was decreased by L-theanine treatments (Quadratic, $P<0.01$ ), while its expression levels in the treatments of 50 and $400 \mathrm{mg} / \mathrm{kg}$ L-theanine were lower $(P<$ $0.01)$ than that of control group and $200 \mathrm{mg} / \mathrm{kg} \mathrm{L}$-theanine treatment. Ileac FATP expression was not affected by Ltheanine treatments $(P>0.05)$. Jejunal GPR43 expression was unchanged by L-theanine treatments $(P>0.05)$. However, its expression in the ileum of $50 \mathrm{mg} / \mathrm{kg} \mathrm{L}$-theanine treatment was decreased $(P<0.05)$ compared with control group and $200 \mathrm{mg} / \mathrm{kg}$ L-theanine treatment. GPR120 (jejunum, Linear and Quadratic, $P<0.001$; ileum, Linear, $P<0.001)$ and $F A B P 2$ (jejunum, Linear, $P<0.001$; ileum, Linear and Quadratic, $P<$ 0.001) expression levels were both suppressed by L-theanine treatments.

\section{Discussion}

To the best of our knowledge, this experiment is a new attempt to investigate the link between serum nutrients and the expression of nutrient-associated transporters and receptors in the small intestine of L-theanine-administered rats. In this study, the declines of glucose, insulin, and urea in the serum were observed by L-theanine administration, indicating that L-theanine could inhibit the absorption of glucose, nitrogen, and secretion of insulin. Our results are partly in line with the data of Yamada et al. (2008) which observed reduced insulin level with unchanged glucose concentration in the serum of rats administrated by $4 \mathrm{~g} / \mathrm{kg}$ oral L-theanine. These results are inconsistent with the findings of Zheng et al. (2004) which discovered that TG and NEFA levels in the serum of mice were decreased by $0.03 \%$ L-theanine administration. This discrepancy appears to be due to the dosage of L-theanine ingested, method of administration, and experimental period.

The upregulating effects of L-theanine are reflected in the AA transporters expression at the mRNA level in small intestine in this study, except SLCla2. This finding can partly explain the increased AAs concentrations in rat serum after L-theanine ingestion [11], including acidic acid (aspartic acid and glutamic acid), neutral acid (glutamine), and basic acid (histidine) (see Supplemental Table 1 in [11]; see Supplementary Material available online at https://doi.org/10.1155/2017/9747256), indicating that Ltheanine promotes the AAs absorption in rat small intestine. The opposing effect of L-theanine on jejunal SLCla2 expression was observed, reflecting that asparagine absorption in 
TABLE 4: Effects of L-theanine administration on the transcript levels of glucose transporters and receptors in rat intestine.

\begin{tabular}{|c|c|c|c|c|c|c|}
\hline \multirow{2}{*}{ Item } & \multicolumn{4}{|c|}{ Treatments $(\mathrm{mg} / \mathrm{kg} \mathrm{BW} \cdot \mathrm{d})$} & \multicolumn{2}{|c|}{$P$ value } \\
\hline & 0 & 50 & 200 & 400 & Linear & Quadratic \\
\hline \multicolumn{7}{|l|}{ Jejunum } \\
\hline SGLT1 & $1.00^{\mathrm{ab}}$ & $1.14 \pm 0.20^{\mathrm{ab}}$ & $0.80 \pm 0.21^{\mathrm{b}}$ & $1.65 \pm 0.21^{\mathrm{a}}$ & NS & NS \\
\hline SGLT3 & $1.00^{\mathrm{ab}}$ & $1.06 \pm 0.15^{\mathrm{a}}$ & $0.53 \pm 0.16^{\mathrm{b}}$ & $0.03 \pm 0.15^{\mathrm{c}}$ & $<0.001$ & NS \\
\hline GLUT2 & $1.00^{\mathrm{ab}}$ & $1.44 \pm 0.2^{\mathrm{a}}$ & $0.77 \pm 0.20^{\mathrm{b}}$ & $1.12 \pm 0.17^{\mathrm{ab}}$ & NS & NS \\
\hline GLUT5 & $1.00^{\mathrm{a}}$ & $0.16 \pm 0.08^{c}$ & $0.72 \pm 0.10^{\mathrm{b}}$ & $0.68 \pm 0.10^{\mathrm{b}}$ & NS & NS \\
\hline \multicolumn{7}{|l|}{ Ileum } \\
\hline SGLT1 & $1.00^{\mathrm{a}}$ & $0.60 \pm 0.12^{\mathrm{b}}$ & $0.17 \pm 0.11^{c}$ & $1.10 \pm 0.09^{\mathrm{a}}$ & NS & $<0.001$ \\
\hline SGLT3 & $1.00^{\mathrm{a}}$ & $0.61 \pm 0.07^{\mathrm{b}}$ & $0.26 \pm 0.06^{\mathrm{c}}$ & $0.01 \pm 0.005^{\mathrm{d}}$ & $<0.001$ & $<0.001$ \\
\hline GLUT2 & $1.00^{c}$ & $3.07 \pm 0.30^{\mathrm{a}}$ & $1.31 \pm 0.33^{\mathrm{bc}}$ & $1.99 \pm 0.30^{\mathrm{b}}$ & NS & NS \\
\hline GLUT5 & $1.00^{\mathrm{a}}$ & $0.58 \pm 0.10^{\mathrm{b}}$ & $0.53 \pm 0.11^{\mathrm{b}}$ & $0.46 \pm 0.11^{\mathrm{b}}$ & 0.003 & NS \\
\hline
\end{tabular}

BW: body weight, SGLT1: sodium dependent glucose transporter 1, SGLT3: sodium dependent glucose transporter 3, GLUT2: glucose transporter protein, member 2, GLUT5: glucose transporter protein, member 5, and NS: not significant. ${ }^{\text {a-d }}$ Means within a row not bearing a common superscript letter differ $(P$ $<0.05)$. Data were reported as mean $\pm \mathrm{SE}$.

TABLE 5: Effects of L-theanine administration on the transcript levels of fatty acid transporters and receptors in rat intestine.

\begin{tabular}{|c|c|c|c|c|c|c|}
\hline \multirow{2}{*}{ Item } & \multicolumn{4}{|c|}{ Treatments $(\mathrm{mg} / \mathrm{kg} \mathrm{BW} \cdot \mathrm{d})$} & \multicolumn{2}{|c|}{$P$ value } \\
\hline & 0 & 50 & 200 & 400 & Linear & Quadratic \\
\hline \multicolumn{7}{|l|}{ Jejunum } \\
\hline FATP & $1.00^{\mathrm{ab}}$ & $0.27 \pm 0.03^{\mathrm{b}}$ & $1.86 \pm 0.07^{\mathrm{a}}$ & $0.40 \pm 0.03^{\mathrm{b}}$ & NS & 0.007 \\
\hline GPR43 & 1.00 & $0.79 \pm 0.49$ & $1.23 \pm 0.57$ & $0.86 \pm 0.61$ & NS & NS \\
\hline GPR120 & $1.00^{\mathrm{a}}$ & $0.25 \pm 0.03^{\mathrm{b}}$ & $0.18 \pm 0.03^{\mathrm{b}}$ & $0.06 \pm 0.03^{c}$ & $<0.001$ & $<0.001$ \\
\hline$F A B P 2$ & $1.00^{\mathrm{a}}$ & $0.52 \pm 0.08^{\mathrm{b}}$ & $0.51 \pm 0.08^{\mathrm{b}}$ & $0.09 \pm 0.08^{\mathrm{c}}$ & $<0.001$ & NS \\
\hline \multicolumn{7}{|l|}{ Ileum } \\
\hline FATP & 1.00 & $1.52 \pm 0.19$ & $1.00 \pm 0.19$ & $1.76 \pm 0.39$ & NS & NS \\
\hline GPR43 & $1.00^{\mathrm{a}}$ & $0.56 \pm 0.13^{\mathrm{b}}$ & $0.72 \pm 0.14^{\mathrm{ab}}$ & $1.02 \pm 0.14^{\mathrm{a}}$ & NS & 0.07 \\
\hline GPR120 & $1.00^{\mathrm{a}}$ & $0.36 \pm 0.11^{b c}$ & $0.64 \pm 0.11^{\mathrm{b}}$ & $0.21 \pm 0.12^{\mathrm{c}}$ & $<0.001$ & NS \\
\hline$F A B P 2$ & $1.00^{\mathrm{a}}$ & $0.38 \pm 0.05^{\mathrm{b}}$ & $0.16 \pm 0.05^{\mathrm{c}}$ & $0.08 \pm 0.05^{\mathrm{c}}$ & $<0.001$ & $<0.001$ \\
\hline
\end{tabular}

BW: body weight, FATP: fatty acid transport protein, GPR43: G-protein-coupled receptor 43, GPR120: G-protein-coupled receptor 120, FABP2: fatty acid binding protein 2 , and NS: not significant. ${ }^{\mathrm{a}-\mathrm{c}}$ Means within a row not bearing a common superscript letter differ $(P<0.05)$. Data were reported as mean \pm SE.

the jejunum might be blocked by L-theanine. Although direct evidences about the regulatory mechanism of AA transporters transcription by L-theanine are lacking, previous literatures showed that activating transcription factor 4 (ATF4) could transcriptionally upregulate SLC7a1 [24] and regulatory factor X proteins (RFXs) induced mRNA of SLC1a1 [25]. After MatInspector online analysis [26], we find that there are ATF4 binding sites in the promoter regions of SLC7al (between nucleotides +10 and +18 ) and SLC7a9 (between nucleotides -155 and -146) genes and RXFs located in SLC1al (between nucleotides -239 and -86) promoter sequence. Additionally, elements for E-box binding factors $(E B O X)$ and $c A M P-r e s p o n s i v e$ element binding proteins $(C R E B)$ binding are identified in the promoter sequences of SLC1a5, SLC7a1, and SLC7a9 genes. Therefore, we speculated that L-theanine, as an amino acid, changed SLC1a1, SLC1a5, SLC7a1, and SLC7a9 mRNA transcription via acting with $A T F 4, R X F, E B O X$, and $C R E B$ proteins.

Glucose transporting from the intestinal lumen to the blood mainly depends on $\mathrm{Na}^{+}$-glucose cotransporter SGLT1, which absorbs glucose and galactose and the passive glucose transporter GLUT2, which acts as a glucose sensor [27-30].
SGLT3 is also a glucose sensor in cholinergic neurons neighboring enterocytes and induces membrane currents upon $\mathrm{Na}^{+}$-glucose binding [27]. GLUT5 is primarily in charge of fructose absorption into the cytosol. Although decreases in SGLT1 and GLUT2 mRNA abundance in the intestine of rats receiving $200 \mathrm{mg} / \mathrm{kg} \mathrm{L}$-theanine, in which glucose absorption was declined, were not observed in this study, we found that intestinal SGLT3 and ileac GLUT5 transcripts in Ltheanine-ingested rats were decreased in a dose-dependent manner. These results indicated that rats intestinal GLUT2 was less impressible than GLUT5 to L-theanine administration at the transcriptional level, and SGLT3 and GLUT5 genes rather than SGLT1 and GLUT2 play a role in intestinal glucose absorption of L-theanine-ingested rats. It is reported that period circadian clock 1 (PER1) exerted an indirect suppressive effect on rat SGLT1 promoter [31] and hepatic nuclear factors (HNF) regulated SGLT1 and GLUT2 promoter activities [32, 33]. By analyzing [26], we also identified $H N F$-element located in SGLT3 and peroxisome proliferatoractivated receptor (PPARG) element encompassed in GLUT5 promoter regions. Therefore, we predicted that L-theanine may target transcription factors (PER1, HNF, and PPARG) 
and further inhibit the expression of glucose transporters mRNA.

It is reported that GPR43 binds short-chain fatty acids, whereas GPR120 responds to medium and long chain fatty acids [34, 35]. FABP2 also displays high-affinity binding for long chain fatty acids and is believed to be involved with uptake and trafficking of lipids in the intestine [21]. In the present study, GPR120 and FABP2 transcripts in jejunum and ileum were decreased by L-theanine. Jejunal FATP mRNA was also suppressed by $50 \mathrm{mg} / \mathrm{kg}$ and $400 \mathrm{mg} / \mathrm{kg}$ L-theanine. However, triglyceride and cholesterol contents in the serum of L-theanine-treated rats were not affected (Table 2). These results state that the intestinal uptake of dietary fatty acids might have been inhibited by L-theanine. Further research is needed to explore the regulatory mechanism of L-theanine on intestinal uptake of dietary lipids.

In summary, L-theanine administration had decreased serum glucose probably by inhibiting intestinal SGLT3 and GLUT5 mRNA expression in rats. Dietary fatty acids uptake might be suppressed by downregulating GPR120 and FABP2 transcripts in the intestine of rats. Meanwhile, intestinal transporters responding to AAs absorption were upregulated by L-theanine administration. Our data provide theoretical basis for further investigation of L-theanine and nutrients interaction.

\section{Abbreviations}

\begin{tabular}{|c|c|}
\hline AA: & Amino acid \\
\hline ATF4: & Activating transcription factor 4 \\
\hline cDNA: & Complementary DNA \\
\hline CREB: & cAMP-responsive element binding proteins \\
\hline $\mathrm{ddH}_{2} \mathrm{O}:$ & Distilled water \\
\hline$E B O X:$ & E-box binding factors \\
\hline ELISA: & Enzyme-linked immunosorbent assay \\
\hline FABP2: & Fatty acid binding protein 2 \\
\hline FATP: & Fatty acid transport protein \\
\hline GLUT2: & Glucose transporter protein, member 2 \\
\hline GLUT5: & Glucose transporter protein, member 5 \\
\hline GPR43: & G-protein-coupled receptor 43 \\
\hline GPR120: & G-protein-coupled receptor 120 \\
\hline HDL: & High-density lipoprotein cholesterol \\
\hline HNF: & Hepatic nuclear factors \\
\hline LDL: & Low-density lipoprotein cholesterol \\
\hline mRNA: & Messenger RNA \\
\hline NEFA: & Non-esterified fatty acids \\
\hline PER1: & Period circadian clock 1 \\
\hline PPARG: & Peroxisome proliferator-activated receptor \\
\hline RFXs: & Regulatory factor X proteins \\
\hline SLC1a1: & Solute carrier family 1 , member 1 \\
\hline SLC1a2: & Solute carrier family 1 , member 2 \\
\hline SLC1a5: & Solute carrier family 1, member 5 \\
\hline SLC16a10: & Solute carrier family 16 , member 10 \\
\hline SLC7a1: & Solute carrier family 7, member 1 \\
\hline SLC7a9: & Solute carrier family 7, member 9 \\
\hline SGLT1: & Sodium dependent glucose transporter 1 \\
\hline SGLT3: & Sodium dependent glucose transporter 3 \\
\hline SD: & Sprague Dawley \\
\hline TG: & Triglyceride. \\
\hline
\end{tabular}

\section{Conflicts of Interest}

The authors declare that there are no conflicts of interest regarding the publication of this article.

\section{Acknowledgments}

This work was supported by the National Natural Science Foundation of China (Grant nos. 31402112, 31320103917, and 31172234), Strategic Priority Research Program-Climate Change: Carbon Budget and Relevant Issues (Grant no. XDA05020700), Youth Innovation Team Project of ISA, CAS (2017QNCXTD_ZCS), and Hunan Provincial Creation Development Project (2013TF3006).

\section{References}

[1] D. C. Chu, "Green tea-its cultivation, processing of the leaves for drinking materials, and kinds of green tea," in Chemistry and Applications of Green Tea, T. Yamamoto, L. R. Juneja, D. C. Chu, and M. Kim, Eds., pp. 1-11, CRC Press, Boca Raton, 1997.

[2] Q. V. Vuong, M. C. Bowyer, and P. D. Roach, "L-Theanine: Properties, synthesis and isolation from tea," Journal of the Science of Food and Agriculture, vol. 91, no. 11, pp. 1931-1939, 2011.

[3] G. Zheng, K. Sayama, T. Okubo, L. R. Juneja, and I. Oguni, "Anti-obesity effects of three major components of green tea, catechins, caffeine and theanine, in mice," In Vivo, vol. 18, no. 1, pp. 55-62, 2004.

[4] K. Sayama, S. Lin, G. Zheng, and I. Oguni, "Effects of green tea on growth, food utilization and lipid metabolism in mice," In Vivo, vol. 14, no. 4, pp. 481-484, 2000.

[5] Y. Takagi, S. Kurihara, N. Higashi et al., "Combined administration of L-cystine and L-theanine enhances immune functions and protects against influenza virus infection in aged mice," Journal of Veterinary Medical Science, vol. 72, no. 2, pp. 157-165, 2010.

[6] K. Matsumoto, S. Yamamoto, Y. Yoshikawa et al., "Antidiabetic activity of $\mathrm{Zn}$ (II) complexes with a derivative of L-glutamine," Bulletin of the Chemical Society of Japan, vol. 78, no. 6, pp. 10771081, 2005.

[7] N. Kajiwara, Y. Yoshikawa, H. Yasui, and K. Matsumoto, "Experimental observations of anti-diabetic activity of zinc complexes with theanine," Annals of Nutrition and Metabolism, vol. 63, pp. 1632-1632, 2013.

[8] T. Terashima, J. Takido, and H. Yokogoshi, “Time-dependent changes of amino acids in the serum, liver, brain and urine of rats administered with theanine," Bioscience, Biotechnology and Biochemistry, vol. 63, no. 4, pp. 615-618, 1999.

[9] S. Kitaoka, H. Hayashi, H. Yokogoshi, and Y. Suzuki, "Transmural potential changes associated with the in vitro absorption of theanine in the guinea pig intestine," Bioscience, Biotechnology and Biochemistry, vol. 60, no. 11, pp. 1768-1771, 1996.

[10] T. Kakuda, E. Hinoi, A. Abe, A. Nozawa, M. Ogura, and Y. Yoneda, "Theanine, an ingredient of green tea, inhibits $[3 \mathrm{H}]$ glutamine transport in neurons and astroglia in rat brain," Journal of Neuroscience Research, vol. 86, no. 8, pp. 1846-1856, 2008.

[11] H. O. Tong, C. J. Li, Q. X. Yan, Z. L. Tan, and X. F. Han, "Effects of $L$-theanine on serum and liver amino acid compositions in weaning rats," Food science, pp. 247-252, 2016.

[12] T. Sugiyama, Y. Sadzuka, K. Tanaka, and T. Sonobe, "Inhibition of glutamate transporter by theanine enhances the therapeutic 
efficacy of doxorubicin," Toxicology Letters, vol. 121, no. 2, pp. 89-96, 2001.

[13] T. Sugiyama and Y. Sadzuka, "Theanine and glutamate transporter inhibitors enhance the antitumor efficacy of chemotherapeutic agents," Biochimica et Biophysica Acta - Reviews on Cancer, vol. 1653, no. 2, pp. 47-59, 2003.

[14] T. Yamada, Y. Nishimura, T. Sakurai et al., "Administration of theanine, a unique amino acid in tea leaves, changed feedingrelating components in serum and feeding behavior in rats," Bioscience, Biotechnology and Biochemistry, vol. 72, no. 5, pp. 1352-1355, 2008.

[15] M. Veyhl, J. Spangenberg, B. Püschel et al., "Cloning of a membrane-associated protein which modifies activity and properties of the Na+-D-glucose cotransporter," Journal of Biological Chemistry, vol. 268, no. 33, pp. 25041-25053, 1993.

[16] G. L. Kellett and P. A. Helliwell, "The diffusive component of intestinal glucose absorption is mediated by the glucoseinduced recruitment of GLUT2 to the brush-border membrane," Biochemical Journal, vol. 350, no. 1, pp. 155-162, 2000.

[17] S. Tazawa, T. Yamato, H. Fujikura et al., "SLC5A9/SGLT4, a new $\mathrm{Na}+$-dependent glucose transporter, is an essential transporter for mannose, 1, 5-anhydro-D-glucitol, and fructose," Life Sciences, vol. 76, no. 9, pp. 1039-1050, 2005.

[18] S. Karaki, R. Mitsui, H. Hayashi et al., "Short-chain fatty acid receptor, GPR43, is expressed by enteroendocrine cells and mucosal mast cells in rat intestine," Cell and Tissue Research, vol. 324, no. 3, pp. 353-360, 2006.

[19] I. Kaji, S.-I. Karaki, R. Tanaka, and A. Kuwahara, "Density distribution of free fatty acid receptor 2 (FFA2)-expressing and GLP-1-producing enteroendocrine L cells in human and rat lower intestine, and increased cell numbers after ingestion of fructo-oligosaccharide," Journal of Molecular Histology, vol. 42, no. 1, pp. 27-38, 2011.

[20] S. J. Paulsen, L. K. Larsen, G. Hansen, S. Chelur, P. J. Larsen, and N. Vrang, "Expression of the fatty acid receptor GPR120 in the gut of diet-induced-obese rats and its role in GLP-1 secretion," PLoS ONE, vol. 9, no. 2, Article ID e88227, 2014.

[21] A. M. Gajda and J. Storch, "Enterocyte fatty acid-binding proteins (FABPs): different functions of liver and intestinal FABPs in the intestine," Prostaglandins Leukotrienes and Essential Fatty Acids, vol. 93, pp. 9-16, 2015.

[22] C. Li, H. Tong, Q. Yan et al., "L-theanine improves immunity by altering th2/th1 cytokine balance, brain neurotransmitters, and expression of phospholipase c in rat hearts," Medical Science Monitor, vol. 22, pp. 662-669, 2016.

[23] K. J. Livak and T. D. Schmittgen, "Analysis of relative gene expression data using real-time quantitative PCR and the 2(-Delta Delta C(T)) method," Methods, vol. 25, no. 4, pp. 402408,2001

[24] C. M. Adams, "Role of the transcription factor ATF4 in the anabolic actions of insulin and the anti-anabolic actions of glucocorticoids," Journal of Biological Chemistry, vol. 282, no. 23, pp. 16744-16753, 2007.

[25] K. Ma, S. Zheng, and Z. Zuo, "The transcription factor regulatory factor $\mathrm{X} 1$ increases the expression of neuronal glutamate transporter type 3," Journal of Biological Chemistry, vol. 281, no. 30, pp. 21250-21255, 2006.

[26] K. Cartharius, K. Frech, K. Grote et al., "MatInspector and beyond: promoter analysis based on transcription factor binding sites," Bioinformatics, vol. 21, no. 13, pp. 2933-2942, 2005.

[27] A. Díez-Sampedro, B. A. Hirayama, C. Osswald et al., "A glucose sensor hiding in a family of transporters," Proceedings of the
National Academy of Sciences of the United States of America, vol. 100, no. 20, pp. 11753-11758, 2003.

[28] E. M. Wright, D. D. F. Loo, B. A. Hirayama, and E. Turk, "Surprising versatility of Na+-glucose cotransporters: SLC5," Physiology, vol. 19, no. 6, pp. 370-376, 2004.

[29] M. A. Hediger, E. Turk, and E. M. Wright, "Homology of the human intestinal $\mathrm{Na}+$ /glucose and Escherichia coli Na+/proline cotransporters," Proceedings of the National Academy of Sciences of the United States of America, vol. 86, no. 15, pp. 5748-5752, 1989.

[30] M. A. Hediger, M. J. Coady, T. S. Ikeda, and E. M. Wright, "Expression cloning and cDNA sequencing of the $\mathrm{Na}+$ /glucose co-transporter," Nature, vol. 330, no. 6146, pp. 379-381, 1987.

[31] A. Balakrishnan, A. T. Stearns, S. W. Ashley, D. B. Rhoads, and A. Tavakkolizadeh, "PER1 modulates SGLT1 transcription in vitro independent of E-box status," Digestive Diseases and Sciences, vol. 57, no. 6, pp. 1525-1536, 2012.

[32] D. B. Rhoads, D. H. Rosenbaum, H. Unsal, K. J. Isselbacher, and L. L. Levitsky, "Circadian periodicity of intestinal Na+/glucose cotransporter $1 \mathrm{mRNA}$ levels is transcriptionally regulated," Journal of Biological Chemistry, vol. 273, no. 16, pp. 9510-9516, 1998.

[33] R. Kekuda, P. Saha, and U. Sundaram, "Role of Sp1 and HNF1 transcription factors in SGLT1 regulation during chronic intestinal inflammation," American Journal of PhysiologyGastrointestinal and Liver Physiology, vol. 294, no. 6, pp. G1354G1361, 2008.

[34] N. E. Nilsson, K. Kotarsky, C. Owman, and B. Olde, "Identification of a free fatty acid receptor, FFA2R, expressed on leukocytes and activated by short-chain fatty acids," Biochemical and Biophysical Research Communications, vol. 303, no. 4, pp. 1047-1052, 2003.

[35] A. J. Brown, S. M. Goldsworthy, A. A. Barnes et al., "The orphan G protein-coupled receptors GPR41 and GPR43 are activated by propionate and other short chain carboxylic acids," Journal of Biological Chemistry, vol. 278, no. 13, pp. 11312-11319, 2003. 

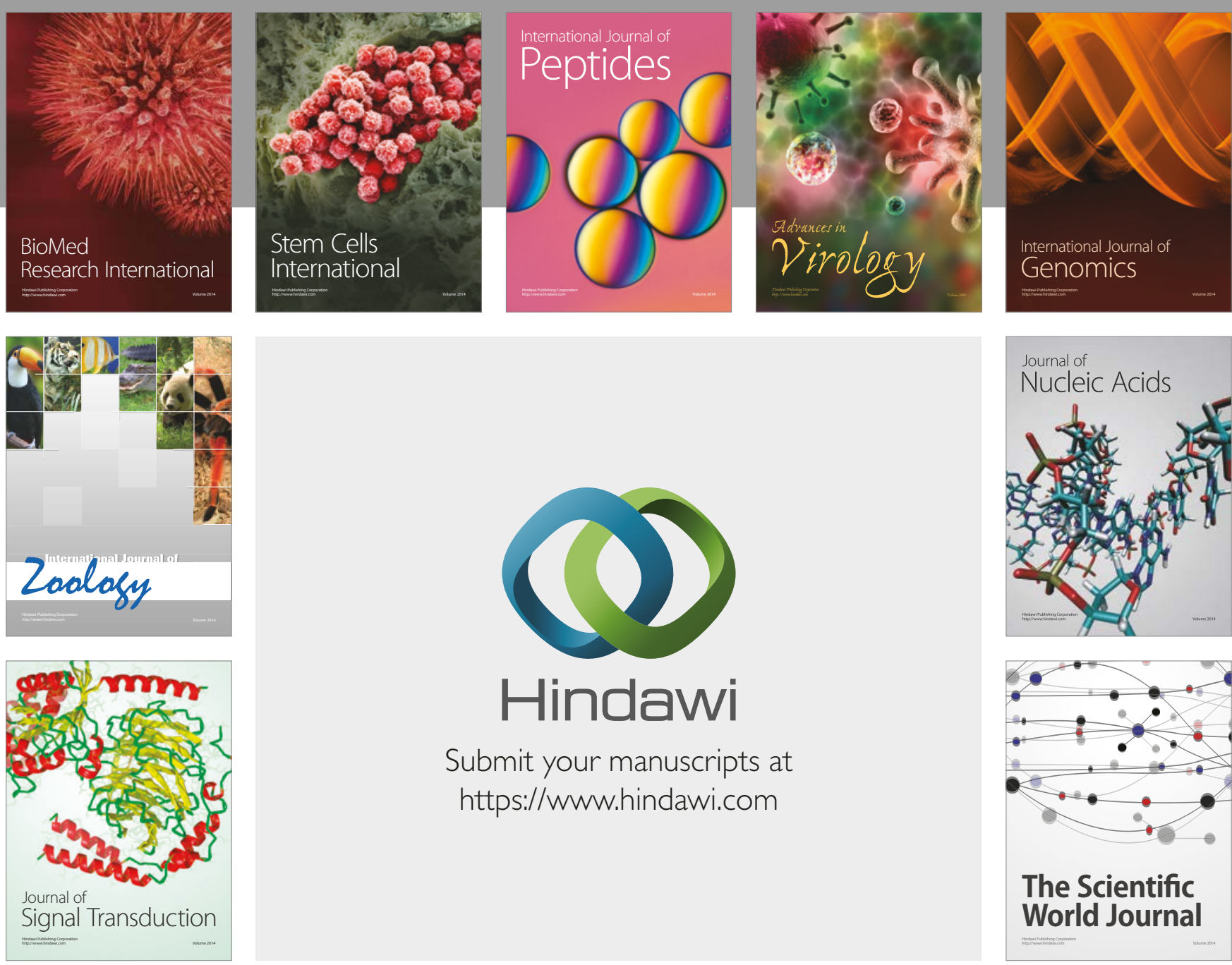

Submit your manuscripts at

https://www.hindawi.com
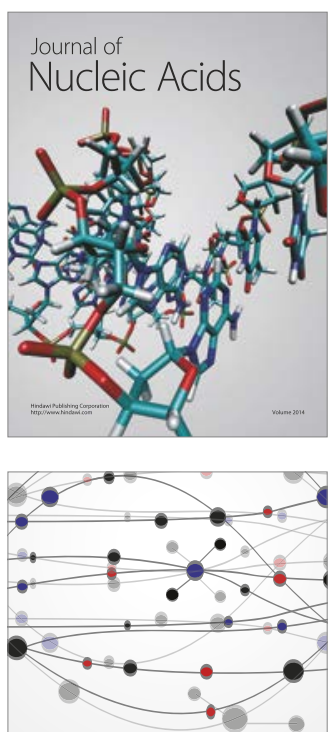

The Scientific World Journal

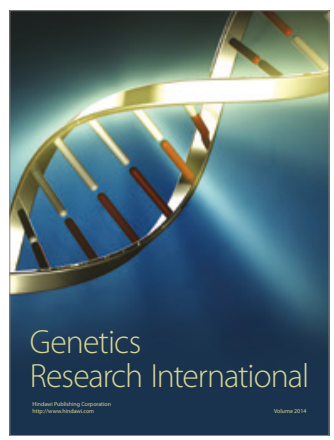

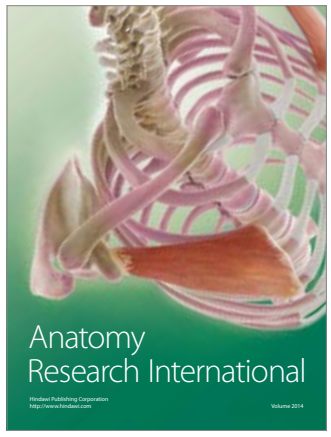

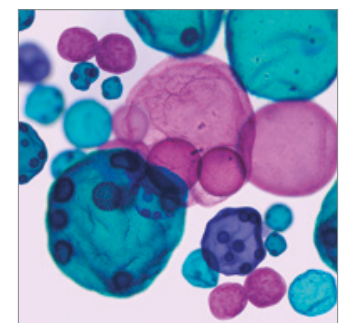

International Journal of Microbiology
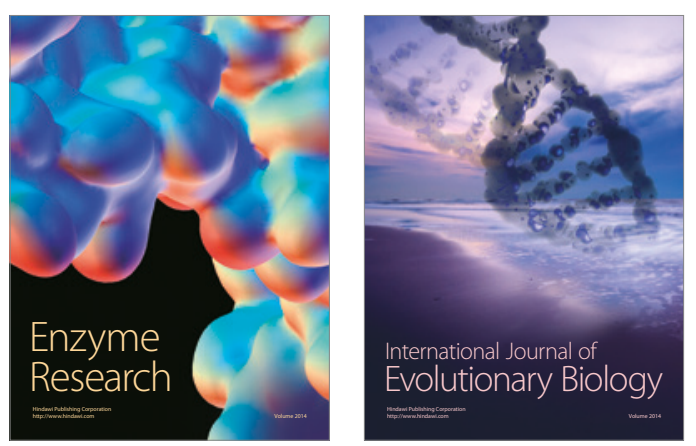
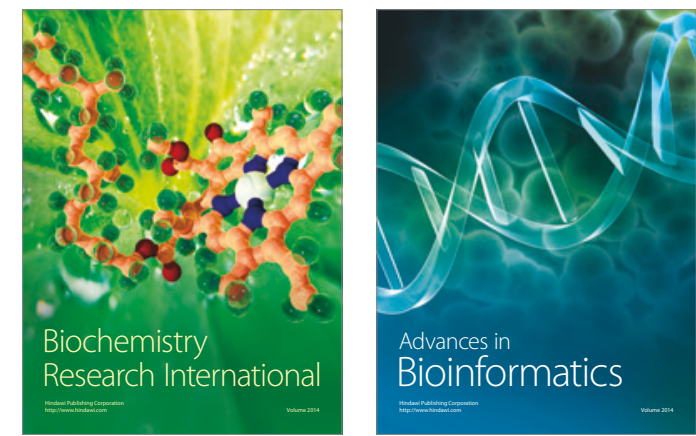

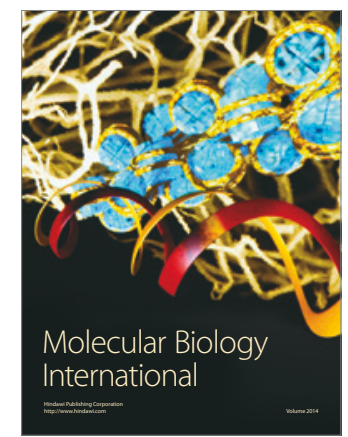

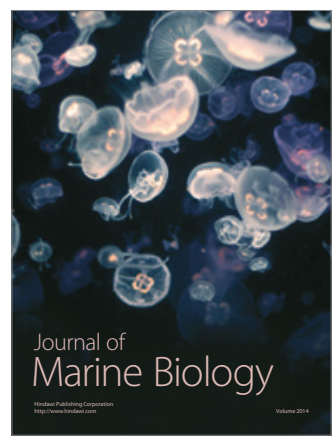

